\title{
AS IMUNIDADES DE JURISDIÇÃO NA JUSTIÇA TRABALHISTA BRASILEIRA*
}

\author{
Guido Fernando Silva Soares \\ Professor Associado do Departamento de Direito Internacional \\ da Faculdade de Direito da Universidade de São Paulo ${ }^{1}$
}

Resumo:

Nas causas, até recentemente julgadas pela Justiça brasileira, relativas a contratos de trabalhos entre indivíduo submetidos à lei brasileira e missões diplomáticas ou repartições consulares sediadas no Brasil, havia o entendimento de que existiriam imunidades de jurisdição, em virtude de serem os empregadores diplomatas ou cônsules estrangeiros. Recente jurisprudência do STF, em matéria trabalhista, passou a considerar que aqueles contratos são relações entre indivíduos submetidos à lei brasileira e, diretamente, Estados estrangeiros, aos quais não se aplicam as regras sobre imunidades de jurisdição, reservadas a diplomatas e cônsules estrangeiros.

\begin{abstract}
:
Until recently in the cases decided by Brazilian Courts relating to labour contracts between individuals submited to the Brazilian Law and foreign diplomatic missions or consular agencies, there was the rule that they were covered by foreign sovereign immunities, due to the fact that employers were foreign diplomats or consuls. Recent cases of the Federal Supreme Court, however, in the matter of labour relations, have decided that such labour contracts deal with relationships between individuals submitted to the Brazilian Law and foreign States themselves, in which regard there is no room for application of the foreign sovereign immunities rule, which must be understood only in relation to foreign diplomats and consuls.
\end{abstract}

* São Paulo, 16 de abril de 1992.

1. Responsável nos cursos de graduação em Direito, pelas seguintes disciplinas: "Direito Internacional Privado", "Direito do Comércio Internacional"e "Direito Processual Internacional". Nos cursos de pós-graduação em Direito Internacional, é o responsável pelas disciplinas: "Teoria Geral do Direito Internacional" e "Soluções Pacíficas de Litígios Internacionais". Atualmente é o chefe do Departamento de Direito Internacional da Faculdade de Direito da Universidade de São Paulo, por eleição de seus pares. 
O tema das imunidades de jurisdição, invocado perante tribunais dos Estados, é recente no Direito Internacional, embora o fenômeno, em algumas de suas manifestações (em particular, no relativo a diplomatas e pessoal lotado em repartições consulares) possa ser vislumbrado em épocas antigas, na medida em que pessoas ou lugares estavam fora da jurisdição local das autoridades. Assim, os governantes estrangeiros recebidos em visita oficial, seus emissários (em particular em épocas de guerras ou de hostilidades), eram considerados como pessoas que não podiam ser submetidas às autoridades da cidade ou do povo que visitavam. Da mesma forma, alguns lugares, considerados sagrados, como os templos ou cemitérios, eram colocados sob a proteção dos deuses (no caso da Grécia antiga, dos deuses do Olimpo, e não dos deuses locais, os deuses epônimos), o que lhes dava o privilégio de poder oferecer asilo a perseguidos pelas autoridades, ou de serem lugares de refúgio e refrigério, nas épocas de guerras localizadas (como o Templo de Epidauro).

$\mathrm{Na}$ sua origem, pois, as denominadas imunidades de jurisdição tinham um efeito pleno. As mencionadas pessoas e lugares eram consideradas acima da lei local, não unicamente nos seus aspectos processuais, mas, na verdade, no sentido de estarem supra legem, em virtude de serem regidos por uma lei supra-humana, a lei divina. Tais concepções sofrerão algumas variações na história do Direito Internacional, e, na Idade Média (quando imperava o conceito de que a lei tinha uma eficácia unicamente pessoal, e em que o território não era ainda o elemento fundamental para determinar a eficácia e vigência do direito), as imunidades, sobretudo dos governantes estrangeiros, ou de seus enviados diplomáticos, eram explicadas com base num costume próprio das organizações estamentais daquele período: "par in parem non habet judicium".

Com a derrocada do personalismo do direito, conforme vigente no período medieval e a instauração do Estado, fortemente assentado numa base territorial, as imunidades passaram a ser explicadas pelo princípio da "extraterritorialidade". Aquelas pessoas e lugares eram, por uma ficção, consideradas como se estivessem "fora do território", e sua situação de nãosubmissão à lei local era devida ao fato de serem elas verdadeiras extensões físicas do governante estrangeiro, no caso de lugares imunes, ou de representação direta, no caso de enviados diplomáticos. $\mathrm{O}$ grande expoente da 
teoria da extraterritorialidade foi Hugo Grotius (1583-1645), considerado como um dos fundadores do Direito Internacional.

Algo tardou para que a teoria da extraterritorialidade de Hugo Grotius fosse suplantada por outra, a de Eméric Vattel (1714-1767), segundo a qual, o fundamento dos privilégios e imunidades de locais e pessoas se baseiam no respeito devido à função que exercem ("ne impediatur officium") ou à sua representatividade ("ne impediatur legatio"). Na verdade, tal é a teoria atual, conforme se pode depreender dos preâmbulos das duas convenções internacionais que regulam o exercício das funções diplomáticas (a Convenção de Viena sobre Relações Diplomáticas, de 18 de abril de 1961, promulgada no Brasil com o Decreto n. 56.435 de 08.06.1965) e das funções consulares (a Convenção de Viena sobre Relações Consulares, de 24 de abril de 1963, promulgada com o Decreto n. 61.078 de 26.06.1967). Eis seus termos:

'reconhecendo que a finalidade de tais privilégios $e$ imunidades não é beneficiar indivíduos, mas sim, a de garantir o eficaz desempenho das funçōes diplomáticas, em seu caráter de representantes dos Estados..." (Convenção de Viena sobre Relações Diplomáticas);

"convencidos de que a finalidade de tais privilégios não é beneficiar indivíduos, mas assegurar o eficaz desempenho das repartiçōes consulares, em nome de seus respectivos Estados..." (Convenção de Viena sobre Relações Consulares).

Conforme dissemos, o tema das imunidades de jurisdição é recente nos dias atuais, em especial, no que se refere à sua invocação constante perante tribunais dos Estados. Em épocas anteriores, as imunidades e os privilégios de diplomatas e cônsules estrangeiros eram postuladas perante os próprios governantes que os recebiam (ou seja, os Poderes Executivos, em suas mais variadas manifestações, como o Chefe de Estado, a autoridade policial ou dos Ministérios Públicos, a administração tributária geral ou a alfandegária, etc.) e, nos raros casos em que os Poderes Judiciários eram chamados a pronunciar-se, o faziam por questões personalíssimas relacionadas diretamente a diplomatas ou cônsules estrangeiros (como as questões de cobrança de dívidas pessoais, ações 
sucessórias, e em notáveis e célebres questões de natureza criminal, estas, em geral, ligadas a crimes de alta traição, espionagem, etc.). As primeiras questões que a doutrina internacional aponta, relacionadas a decisões judiciais dos tribunais internos dos Estados, sobre imunidades de jurisdição, dizem respeito a atos praticados, não no exercício das funções diplomáticas ou consulares, mas em assuntos relativos à própria participação do Estado estrangeiro em atividades corriqueiras no território dos Estados que recebiam os agentes estrangeiros.

Na verdade, a emergência do tema das imunidades de jurisdição (e, conseqüentemente, o tema das imunidades de execução) na sua versão corrente nos dias atuais, ou seja, das imunidades do próprio Estado estrangeiro, deve ser creditada, pelo menos, a dois fenômenos típicos do século XX:

a. a freqüência da prática de determinados atos pelo próprio Estado, que, em épocas anteriores, se tinha abstido de realizar, dada a concepção dominante de que se tratava de um campo reservado aos particulares (a concepção liberal de que ao Estado estavam proibidas atividades de intervenção no domínio econômico, cidadela reservada à iniciativa privada, onde imperava o mais pleno princípio da autonomia da vontade dos contratantes particulares);

b. a superação do princípio de que a Administração Pública, por ser um órgão do Estado, não poderia submeter-se à jurisdição dos tribunais do seu próprio Estado, uma vez que se tinha a concep̧ão generalizada de que a ação dos Poderes Executivos seria sempre conforme às normas jurídicas (era a regra tão bem expressa pela Common Law inglesa: "the King can do no wrong", ou melhor dito, "the Queen can do no wrong", pois à época da Rainha Victoria é que se pode ter como imperante tal princípio da legalidade intrínseca dos atos do Governo e da sua inatacabilidade perante os tribunais nacionais).

Ora, na medida em que se torna corrente a prática pelo próprio Estado de atos anteriormente reservados à iniciativa dos particulares, e em que os Poderes Judiciários estendem sua jurisdição para abarcar os atos assim praticados, começam a surgir os primeiros casos em que são invocadas as imunidades do Estado estrangeiro perante os tribunais daqueles Estados, seja onde estão postados seus agentes diplomáticos ou consulares, seja onde seus atos produzirão efeitos. Foi assim que, aos poucos, em particular na jurisprudência federal dos EUA, foi surgindo a distinção entre, de um lado, as questões das imunidades de jurisdição (foreign sovereign immunities), para os atos praticados 
pelos agentes do Estado estrangeiro, e de outro lado, as questões relacionadas com os efeitos no território de um Estado, dos atos praticados pelo Estado estrangeiro alhures (o princípio do Act of State Doctrine).

Uma questão curiosa a ser desvendada é aquela relativa às razões da freqüência crescente com que os funcionários dos Estados estrangeiros têm sido trazidos às barras dos tribunais judiciários nacionais dos Estados, na atualidade. Um levantamento das questôes versadas, pelo menos nas Capitais (onde se localizam as missões diplomáticas) e nas grandes cidades (onde estão as repartições consulares) revelassem, talvez, tratar-se de um agigantamento das representações estrangeiras e a presença, cada vez maior nos países, de estrangeiros residentes portadores de privilégios e imunidades, bem como um crescimento das atribuições das citadas representações, com as conseqüentes questões relacionadas a contratos de trabalho com pessoas locais, questões de inadimplência de contratos de locação de imóveis por funcionários estrangeiros, ou ainda, de acidentes de trânsito, envolvendo diplomatas ou cônsules estrangeiros. Os raros casos de natureza criminal, na verdade, não têm sido apreciados pelos tribunais, tendo-se, antes, preferido uma solução diplomática de pedir a retirada compulsória dos funcionários estrangeiros do território nacional, pelo acionamento do mecanismo da declaração de "persona non grata" (previsto nas convenções internacionais).

Por outro lado, têm ocorrido casos resultantes de inadimplência de contratos de construção de imóveis para sede das representações èstrangeiras, ou ainda, outros relativos a pagamento de débitos da própria missão diplomática ou da representação consular estrangeiras, que, por serem atos do próprio Estado estrangeiro, não podem, em princípio, ser assimiláveis aos atos de seus agentes no exterior. Na verdade, o assunto é complexo, e por isso mesmo, dissemos "em princípio", uma vez que variam os sistemas relacionados com a posse ou propriedade de imóveis em território estrangeiro, para fins da representação diplomática ou da sede de uma repartição consular. Há países em que é o Estado que adquire ou aluga, em nome próprio, o imóvel; outros, em que são proibidas a posse e a propriedade por Estados estrangeiros, de quaisquer imóveis, ainda que para fins de representação oficial (e, por conseguinte, é o Chefe da Missão diplomática ou da repartição consular que os adquire ou aluga, em nome próprio). No direito brasileiro, a lei proíbe a governos estrangeiros, bem como a 
organizações que tenham constituído, que dirijam ou nas quais hajam investido funções públicas, de adquirir bens imóveis ou suscetíveis de desapropriação, salvo no caso de aquisição da propriedade dos prédios necessários à sede dos representantes diplomáticos ou dos agentes consulares, nestes compreendidos, os imóveis para residência dos Agentes Diplomáticos e membros da Missão das respectivas missões diplomáticas (Lei de Introdução ao Código Civil, art. 11, §§ $2^{2}$ e $3^{2}$, bem como a Lei n. 4.331 de 01.06 .1964 , art. $1^{9}$ ).

$\mathrm{O}$ que se pode, desde já, acentuar e o que faremos no decorrer do presente artigo é que se trata de questões distintas:

a. de um lado, as imunidades diplomáticas e consulares, reguladas pelas normas escritas e mais ou menos precisas de duas convenções internacionais, as já citadas Convenções de Viena de 1961 e de 1963, portanto jus scriptum, devidamente incorporadas às legislações domésticas da maioria dos Estados na atualidade;

b. de outro, as imunidades do próprio Estado estrangeiro, que não são reguladas por qualquer norma escrita de Direito Internacional Geral, salvo a Convenção da Basiléia, de 16 de maio de 1962, "Convenção Européia sobre Imunidades do Estado e Protocolo Adicional" (ainda não vigente na esfera internacional dos Estados-partes) mas sim têm sido reguladas por leis escritas internas de alguns Estados, por sinal, pertencentes ao sistema da Common Law, como: os EUA (legislação federal, o Foreign Sovereign Immunities Act 1976, conhecido como FSLA), o Reino Unido (State Immunity Act 1978), Canadá (State Immunity Act 1982), Austrália (Foreign States Immunities Act 1985), Paquistão, e África do Sul, em 1981 e Singapura (State Immunity Act 1979). No caso brasileiro, como veremos, a construção da norma no segundo caso, ou seja, das imunidades do próprio Estado estrangeiro, é de origem jurisprudencial, em particular, originária da jurisprudência gerada em questões laborais, motivo pelo qual elegemos a jurisdição trabalhista como ponto de análise do tema das imunidades de jurisdição.

Em um campo de tal maneira lacunoso e importante, deve-se ressaltar a posição da doutrina dos internacionalistas e do direito comparado. Para unicamente ficar nos cursos da Academia de Direito Internacional da Haia, e em temas monográficos especiais sobre o assunto, podemos citar: A. Weiss, Compétence ou incompétence des tribunaux à l'égard des Ettats étrangers, Recueil 
des Cours, v. 1 (1923); Sir Cecil Hurst, Les immunités diplomatiques, Recueil, (1926); Jean-Flavien Lalive, L'immunité de juridiction des États et des organisations internationales, Recueil, (1953-III); Mario Giuliano, Les relations et immunités diplomatiques, Recueil, (1960, v. 100); N.C.Dunbar, Controversial aspects of sovereign immunity in the case law of some States, Collected Courses (1971, v. 132); Sompong Sukharitkul, Immunities of foreign States before national authorities, Collected Courses, (1976, v. 149); Sir Ian Sinclair, The law of sovereign immunity, Recent development, Collected Courses (1980, v. 167); e Peter D. Trooboff, Foreign State immunity: emerging consensus on principles, Collected Courses (1986-V). No campo da doutrina recente brasileira, remetemos o leitor para a bibliografia constante no final do presente artigo; para a doutrina anterior a 1980, remetemo-lo para nosso livro: Das imunidades de jurisdiçāo e de execução, Rio de Janeiro, Forense, 1984.

$\mathrm{O}$ assunto das imunidades de jurisdição, por outro lado, ocupa um lugar especial nas considerações sobre as relações entre o Direito Internacional e os direitos internos dos Estados. Em qualquer outro ramo do Direito Internacional, as questões suscitadas no que se refere a tais relações, sempre diziam respeito a problemas de hierarquia das normas, em particular, no que se refere a eventual derrogação ou abrogação das normas domésticas dos Estados, por força daquelas elaboradas nos foros legisferantes internacionais, mas sempre com o pressuposto de que quem iria decidir sobre tais questões, seria um juiż nacional (ou eventualmente um juiz criado pela própria norma internacional). Já no caso das imunidades de jurisdição, o que se discute é a própria existência deste poder dos tribunais nacionais de poderem dirimir controvérsias sobre sua própria competência. O que é mais intrigante, no caso, é que se tem de conviver, num ramo tão nacionalista como o Direito Processual, com exceções que o mesmo não contempla, e em assuntos tradicionalmente reservados a normas de ordem pública, e que exigem uma interpretação rígida e restritiva, como é o caso das competências dos juízes e tribunais nacionais e dos motivos de extingüibilidade do processo sem julgamento do mérito.

$\mathrm{Na}$ verdade, as argüições de extingüibilidade do processo pressupóem um processo instaurado perante um juiz ou tribunal, tendo, portanto, havido a existência das preliminares básicas: a competência do órgão judicante (com a ocorrência das hipóteses legais de sua competência, seja a 
internacional, seja a interna) e a presença física ou ficta (através de uma citação válida) da pessoa contra quem se move o processo. Torna-se evidente que o julgador, ao decidir extingüir um processo sem julgamento de mérito, o faz, numa relação processual validamente constituída, durante a qual foram alegados e julgados os motivos que teriam podido solapar as condições de constituição e desenvolvimento válido e regular do processo (conforme o art. 267, IV do Código de Processo Civil brasileiro) ou dado causa a que não ocorressem as condições da ação cível, ou seja: a possibilidade jurídica, a legitimidade das partes e o interesse processual (art. 267 do CPC, VI). O que não contempla o Código de Processo Civil brasileiro (et pour cause a lei processual trabalhista) é a impossibilidade de uma não-resposta a uma citação válida ter o efeito de não se configurar em revelia, e, por outro lado, dar motivo à extinção do processo, por impossibilidade jurídica! No entanto, é o que se tem verificado, em particular nos assuntos trabalhistas e, até há pouco tempo, na jurisprudência brasileira dos mais altos Tribunais federais, em que a recusa de comparecimento de missões diplomáticas ou de repartições consulares estrangeiras (e, em certos casos, nem sequer para contestar a jurisdição dos juízes brasileiros) se tenha configurado numa impossibilidade jurídica de constituição do processo civil, com a conseqüente decisão de extingüir-se o feito sem julgamento do mérito.

No presente estudo, não trataremos das questões das imunidades de pessoas empregadas por organizações internacionais e que se encontrem no Brasil. $\mathrm{O}$ assunto é diverso, pois que regido por normas distintas daquelas que regem pessoal a serviço de Governos estrangeiros, como os diplomatas e cônsules postados no nosso País, ou de pessoas empregadas dos Governos estrangeiros, em relações trabalhistas.

Passando, pois, ao estudo do caso brasileiro, no que se refere a pessoas físicas abrangidas pelos privilégios e imunidades, trata-se daquelas que se encontram no território nacional, em exercício de uma função oficial, a serviço de um Estado estrangeiro: diplomatas ${ }^{2}$ (funcionários estrangeiros em

2. "Diplomata", no direito brasileiro, tem duas acepçōes: "lato sensu", designa o funcionário público federal, da carreira diplomática, que pode tanto estar lotado na Secretaria de Estado das Relações Exteriores, em Brasília, quanto estar em posto numa missão diplomática na Capital de um Estado estrangeiro, ou em uma representaçāo do Brasil junto a alguma organizaçāo internacional, numa cidade no exterior (e nesses dois casos, charmar-se-á "diplomata" "stricto 
determinadas funções nas Embaixadas estrangeiras sediadas na Capital Federal, Brasilia, DF) e vice-cônsules, cônsules, cônsules-gerais e cônsules honorários (determinados funcionários em posto nas repartiçôes consulares estrangeiras nas principais cidades brasileiras, ou naquelas de importância para seus países). Por outro lado, não são todas as pessoas lotadas em tais repartições diplomáticas ou consulares que estão acobertadas pelas imunidades e privilégios, diplomáticos ou consulares, uma vez que as próprias normas das duas Convenções de Viena estabelecem pré-requisitos e exceções.

Quanto a pessoas encontráveis em missões diplomáticas estrangeiras no Brasil, deve distinguir-se na letra da Convenção de Viena sobre Relações Diplomáticas de 1961:

a. o agente diplomático, ou seja: o Chefe da missão diplomática e os "membros do pessoal de missão" que tiverem a qualidade de diplomatas (art. $1^{\mathrm{Q}}, d$ e $e$ );

b. os membros do pessoal administrativo e técnico, quer dizer: os membros do pessoal da missão empregados no serviço administrativo e técnico da mesma (art. 19, $f$ ), como os burocratas designados a secretariar trabalhos da rotina administrativa, e além do mais, os arquivistas, criptógrafos, encarregados de telecomunicações, técnicos em vários ramos a que se dedique a missão diplomática;

c. os membros do pessoal de serviço da missão diplomática, empregados no serviço doméstico da mesma (art. 1o, $g$ ) como copeiros, cozinheiros, jardineiros, motoristas (e que por comparação com o "criado particular", a seguir descrito, sejam empregados do Estado estrangeiro);

d. os criados particulares, definidos como pessoas do serviço doméstico de um membro da Missão que não sejam empregados do Estado acreditante $\left(\operatorname{art.} \mathbf{1}^{\mathbf{0}}, h\right)$, ou seja, pessoal idêntico ao descrito no item c. anterior, mas com a situação de estarem regidos por uma relação privada entre eles e o agente estrangeiro.

sensu"), ou ainda, estar em posto numa repartição consular em alguma cidade no exterior (quanto então sua denominação será de "vice-cônsul", "cônsul" ou "cônsul-geral", dependendo de sua posição na carreira diplomática e da natureza da repartição consular em que estiver postado). Em alguns países, existe uma carreira consular, ao lado da carreira diplomática. 
O "agente diplomático" não tem qualquer tipo de relação trabalhista com o Estado brasileiro, uma vez que suas funções decorrem de uma relação jurídica dele com o seu próprio Estado, funções aquelas regidas pelas normas do Direito Internacional Público (sendo irrelevante o tipo de ligação que o mesmo mantém com o país que ele representa, se de direito administrativo, ou se de direito trabalhista), desde que gozem de situação de "personae gratae" e que tenham sido admitidos no território nacional, com a expressa anuência do Governo brasileiro. ${ }^{3}$ Em regra, o agente diplomático é nacional do Estado acreditante, havendo, contudo, a possibilidade de um diplomata a serviço de uma missão diplomática estrangeira ser brasileiro, com a expressa anuência do Governo brasileiro (art. $8^{\circ}$ da Convenção de Viena de 1961), mas, nesse caso, se tiverem residência permanente no território nacional, gozarão das imunidades de jurisdição e de inviolabilidade pessoal apenas quanto aos atos oficiais praticados no desempenho de suas funções (art. $38, \S 1$, id.). Gozam das imunidades os membros da familia de um agente diplomático, nas condições de com ele viverem e desde que não sejam nacionais do Estado acreditado (ou seja, de não serem brasileiros) (art. 37, $\S 1^{\circ}$ da Convenção de Viena de 1961).

As imunidades de que gozam os agentes diplomáticos são as da jurisdição penal e as da jurisdição cível e trabalhista (sendo que a Convenção de Viena de 1961, no seu art. 31, § $1^{\mathrm{g}}$, se refere à "jurisdição civil e administrativa", entendendo os seus intérpretes que se trata, nesta última, da jurisdição laboral). A própria Convenção de Viena sobre Relações Diplomáticas estabelece as exceções às imunidades da jurisdição cível:

"a. uma ação real sobre imóvel privado situado no território do Estado acreditado, salvo se o agente diplomático o possuir por conta do Estado acreditante para os fins da Missão;

3. No caso do Chefe da Missão, tal anuência se perfaz com a concessão de um "agrément" do Governo brasileiro, e se exterioriza com a entrega solene de suas credenciais ao Chefe de Estado, no Brasil, atualmente, o Presidente da República. No caso de outros membros do pessoal da missão, o fato é perfeito com uma comunicação da chegada do agente em território nacional, pelo Chefe da Missão, às autoridades brasileiras, especificamente, ao Ministério das Relações Exteriores, por nota oficial. 
b. uma ação sucessória na qual o agente diplomático figure, a título privado e não em nome do Estado, como executor testamentário, administrador, herdeiro ou legatário;

c. uma ação referente a qualquer profissão liberal ou atividade comercial exercida pelo agente diplomático no Estado acreditado fora de suas funçöes oficiais".

Ainda nos termos da citada Convenção de Viena de 1961, o agente diplomático não é obrigado a prestar depoimentos como testemunha, nem está sujeito a nenhuma medida de execução, salvo nos casos das exceções mencionadas no $\S 1^{\circ}$ do art. 31 transcrito; no caso de depoimentos prestados nas hipóteses elencadas, eventuais medidas constritivas deverão ser conduzidas sem afetar a inviolabilidade de sua pessoa ou residência.

Quanto ao pessoal administrativo e técnico da Missão diplomática, pode ser composto tanto de nacionais do Estado estrangeiro acreditado, quanto brasileiros. No caso de serem brasileiros e residentes no território nacional, é evidente que existe uma relação trabalhista entre eles e a Missão diplomática, ainda que a citada Convenção de Viena de 1961 seja silente a respeito. O que importa dizer é que a relação trabalhista que se estabelece é entre o Estado estrangeiro e um indivíduo brasileiro (ou nacional daquele país, e em tal caso, é necessário examinar na legislação estrangeira se o contrato é de natureza de Direito Administrativo, tipo funcionário público, ou se de natureza de Direito do Trabalho, para a hipótese de uma pessoa contratada alhures para prestar serviço no Brasil), e não como tem feito entender a jurisprudência brasileira, entre o indivíduo e os membros da Missão diplomática! Na verdade, trata-se de pessoas que têm uma ligação direta com papéis oficiais, com códigos e sistemas de cifragem de mensagens, com o manuseio de verbas orçamentárias de Governos estrangeiros, e eventualmente de contatos oficiais com o público, razões pelas quais se justifica a atribuição dos privilégios e imunidades ratione oficii. Eis os dispositivos da Convenção de Viena de 1961 a respeito dos membros do pessoal administrativo e técnico de uma missão diplomática:

"Art. 37, $\& 2^{o}$ - Os membros do pessoal administrativo e técnico da Missāo, assim como os 
membros de suas famílias que com eles vivam, desde que não sejam nacionais do Estado acreditado nem nele tenham residência permanente, gozarão dos privilégios e imunidades mencionados nos arts. 29 a 35, com a ressalva de que a imunidade de jurisdição civil e administrativa do Estado acreditado, mencionada no § $1^{o}$ do art. 31 não se estenderá aos atos por eles praticados fora do exercício de suas funçōes: gozarão também dos privilégios mencionados no $\$ 1$ do art. 36 , no que respeita aos objetos importados para a primeira instalação".

Da mesma forma, os "membros do pessoal de serviço" de uma Missão diplomática são empregados do Estado estrangeiro, pelas razões já mencionadas. Neste particular, mais do que claro se tornam as finalidades das normas relativas às imunidades de jurisdição: proteger a função diplomática e não as pessoas que as exercem. Da mesma forma, a regulamentação da situação dos "criados particulares dos membros da Missão", revelam tais intuitos da Convenção de Viena sobre Relações Diplomáticas. Vale a pena transcrever os dispositivos relativos aos temas, conforme constantes dos $\$ \S 3^{\circ}$ e $4^{\mathfrak{o}^{\circ}}$ do art. $37 \mathrm{da}$ citada Convenção:

"§ $3^{o}$ - Os membros do pessoal de serviço da Missāo, que não sejam nacionais do Estado acreditado nem nele tenham residência permanente, gozarão de imunidades quanto aos atos praticados no exercício de suas funções, de isenção de impostos e taxas sobre salários que perceberem pelos seus serviços e da isenção prevista no art. 33.

$\S$ 4o - Os criados particulares dos membros da Missão, que não sejam nacionais do Estado acreditado nem neles tenham residência permanente, estão isentos de impostos e taxas sobre salários que perceberem por seus serviços. Nos demais casos, só gozarão de privilégios $e$ imunidades na medida reconhecida pelo 
referido Estado. Todavia, o Estado acreditado deverá exercer a sua jurisdição de modo a não interferir demasiadamente com o desempenho das funçöes da missão".

De igual forma, a jurisprudência brasileira tem laborado em um equívoco, ao assimilar a pessoa do reclamado à pessoa dos diplomatas estrangeiros, em reclamações trabalhistas impetradas contra Missões diplomáticas estrangeiras no Brasil, e, por conseguinte, tem acatado as preliminares de imunidades de jurisdição como se os reclamantes fossem empregados de pessoas imunes. $\mathrm{Na}$ verdade, o vínculo trabalhista que se estabelece (salvo no caso de "criados particulares dos membros da Missão") é entre, de um lado, um trabalhador brasileiro ou estrangeiro, mas "residente no Brasil" (para empregar a terminologia da Convenção de Viena, quando se deveria ter dito domiciliado, numa boa tradução, para o direito brasileiro, de seus termos), e de outro, o próprio Estado estrangeiro, que, pelo menos nos termos da Convenção de Viena de 1961, não possui imunidades de jurisdição.

Quanto ao pessoal lotado em repartições consulares estrangeiras no Brasil (sejam elas Consulados-Gerais, nas grandes cidades, consulados, viceconsulados ou agências consulares, em cidades menores, o que lhes dimensiona o número de seus funcionários) é mister distinguir, como o faz a Convenção de Viena de 1963 sobre Relações Consulares, tratar-se de funçionários consulares de carreira ("toda pessoa, inclusive o Chefe da repartição consular, encarregada nesta qualidade do exercício de funçôes consulares", art. $\left.1^{\underline{o}}, \S 1^{\mathfrak{o}}, d\right)$ ou de funcionários consulares honorários (que a Convenção de Viena de 1963 não define diretamente, mas que expressis verbis, no art. $1^{\underline{o}}$, $\S 2^{\underline{o}}$, faz regular no capítulo III, denominado Regime Aplicável aos Funcionários Consulares Honorários e às Repartiçōes Consulares por Eles Dirigidas). Os cônsules honorários, na verdade, são, em geral, nacionais do Estado receptor, pessoas de elevadas qualidades pessoais e profissionais, que foram eleitas pelo Estado que envia, ${ }^{4}$ para representar-lhes os interesses em matéria consular; a distinção entre

4. Note-se a terminologia de ambas as Convençōes de Viena: naquela sobre relaçōes diplomáticas, as fórmulas utilizadas são Estado acreditante e Estado acreditado; naquela sobre relações consulares, as fórmulas sāo Estado que envia e Estado receptor. 
os funcionários consulares de carreira e os funcionários consulares honorários é antiqüíssima no Direito Internacional, correspondendo aos consules missi e aos consules electi. Estes ainda representam uma forma de homenagear pessoas que prestaram ou podem prestar serviços a um Governo estrangeiro, ou ainda de poder suprir, com a indicação de pessoas locais, uma eventual falha de pessoal altamente preparado no funcionalismo do Estado que envia (ou ainda, por questões de redução de custos operacionais, tendo em vista que os funcionários consulares honorários recebem apenas por seus serviços prestados e não como funcionários do Estado que envia).

Seguindo a sistemática de alguns tratados internacionais, inclusive a Convenção de Viena sobre Relações Diplomáticas de 1961, na qual se inspirou, ${ }^{5}$ a Convenção de Viena sobre Relações Consulares, no seu art. 1ำ, define os termos mais importantes que emprega. Assim, no que interessa ao presente estudo são definidos:

a. funcionário consular, como já dito, "toda pessoa, inclusive o chefe da repartição consular, encarregada nesta qualidade do exercício de funções consulares" (art. 1ํㅗ $§ 1^{\mathbf{o}}, e$ );

b. empregado consular, "toda pessoa empregada nos serviços administrativos ou técnicos de uma repartiçāo consular", (art. $\left.1^{\mathfrak{Q}}, \S 1^{\mathrm{o}}, e\right)$;

5. Na verdade, a Convenção de Viena sobre Relações Diplomáticas de 1961 tinha alguns precedentes históricos notáveis, como as regulamentaçōes existentes em séculos anteriores, tais o Regulamento de Viena de 1815 sobre a Ordem de Precedência dos Agentes Diplomáticos, complementado pelo Protocolo de Aix-la-Chapelle de 1818, ou aquela elaborada sob a égide da organização internacional regional americana, a União Panamericana, antecessora da atual Organizaçāo dos Estados Americanos, OEA, adotada pela VI Conferência Internacional Americana em Havana, a 20 de fevereiro de 1928, "Convenção relativa a Funcionários Diplomáticos". Deve-se ressaltar que esta última foi calcada no Projeto de Código de Direito Internacional Público, (arts. 104 a 150), de 1911, de autoria do então Ministro da Justiça do Brasil, o eminente Epitácio Pessoa. Veja-se, a esse propósito, a insuperável obra do Embaixador Geraldo do Nascimento e Silva, Convenção de Viena sobre Relações Diplomáticas, Brasil, Ministério das Relações Exteriores, Seção de Publicaçōes, 1ª ed., 1967, p. 14-15, ou ainda, sua $A$ missão diplomática, recentemente relançada pela Editora Forense. No caso da Convenção de Viena sobre Relações Consulares, de 1963, o único precedente que os legisladores internacionais contavam, era com a citada Convenção de Viena sobre Relações Diplomáticas, votada anos antes, na mesma Capital austríaca. 
c. membro do pessoal de serviço, "toda pessoa empregada no serviço doméstico de uma repartição consular" (art. $\left.1^{\mathfrak{Q}}, \S 1^{\mathfrak{Q}}, f\right)$;

d. membro do pessoal privado, "a pessoa empregada exclusivamente no serviço pessoal de um membro da repartição consular" (art. $\left.1^{\circ}, \S 1^{\varrho}, i\right)$.

Isto posto, segue-se que, com exceção do "membro do pessoal privado", todas as pessoas que não sejam funcionários consulares de carreira são regidos pela legislação trabalhista brasileira, em função do lugar da prestação do trabalho, sendo claro que o empregador é o Estado estrangeiro, que não se acha diretamente abrangido pela Convenção de Viena sobre Relações Consulares, nos contratos de trabalho que celebra com as citadas pessoas. Neste particular, mais uma vez, é necessário denunciar o equívoco da jurisprudência brasileira que tem assimilado os contratos de trabalho entre uma repartição consular e um empregado contratado no Brasil aos contratos de trabalho entre funcionários consulares (e estes contratos é que são imunes à jurisdição brasileira, em alguns aspectos, como se verá adiante). Relembre-se: por mais paradoxal que possa parecer, os Estados não estão acobertados pelas disposições das Convenções de Viena de 1961 ou de 1963, que, no entanto, concedem imunidades a alguns atos de seus funcionários!

No que diz respeito às imunidades de jurisdição, a Convenção de Viena sobre Relações Consulares é sensivelmente menos abrangente que a Convenção de Viena sobre Relações Diplomáticas:

a. inexiste a imunidade da jurisdição penal plena para os funcionários consulares (que podem ser detidos ou presos preventivamente em caso de crime grave e em decorrência de decisão de autoridade judicial competente, conforme art. $41, \S 1^{\mathrm{o}}$, da Convenção de Viena sobre Relações Consulares);

b. estão os membros de uma repartição consular obrigados a depor como testemunhas, citadas em processo judicial (ou administrativo), por força do art. $44, \S 1^{9}$ (id.).

No que se refere a outras imunidades, assim dispõe o art. 43 da Convenção de Viena sobre Relações Consulares: 


\section{"Artigo 43}

\section{Imunidade de Jurisdição}

1. Os funcionários e os empregados consulares não estão sujeitos à jurisdição das autoridades judiciárias $e$ administrativas do Estado receptor pelo atos praticados no exercício das funções consulares.

2. As disposições do $\S 1^{\circ}$ do presente artigo não se aplicarão, entretanto, no caso de ação civil:

a. que resulte de contrato que o funcionário ou empregado consular não tiver realizado, implícita ou explicitamente como agente do Estado que envia; ou

b. que seja proposta por terceiro, como conseqüência de danos causados por acidente de veículo, navio ou aeronave, ocorrido no Estado receptor".

Quanto aos contratos de trabalho entre uma pessoa brasileira ou um estrangeiro, contratados no Brasil para funções numa repartição consular, é mister analisá-los de acordo com o disposto no supracitado art. $43, \S 2^{2}$. Na sua exegese, verifica-se que existe imunidade de jurisdição naqueles contratos em que o funcionário ou empregado consular agirem, implícita ou explicitamente, no exercício das funções consulares (contrato realizado como agente do Estado estrangeiro).

Ora, a realização de um contrato na qualidade de agente do Estado estrangeiro é típico das funções consulares, o que pressupõe todo o regime de regulamentação unilateral pelo Estado brasileiro dos seguintes aspectos:

a. entrada e permanência dos estrangeiros na qualidade de funcionários consulares (o sistema do exequatur das cartas patentes expedidas pelo Estado estrangeiro, em benefício de seus funcionários, especialmente enviados ao exterior);

b. a atribuição de uma jurisdição consular, sobre parte do território nacional, por parte do Governo federal, por sinal, o único competente para regular, com exclusividade, tais aspectos das relações internacionais do Brasil com países estrangeiros; 
c. a existência de uma autorização implícita para a realização de atos oficiais regulados pela legislação estrangeira, como: a expedição de passaportes aos seus nacionais, registros civis de nascimentos ou óbitos, realização de casamentos consulares entre nacionais de seu país, legalizações de faturas comerciais, de assinaturas de autoridades brasileiras, concessões de todos os tipos de vistos de entrada e permanência, enfim, uma série de atos, inclusive inexistentes no direito brasileiro ou de nenhum efeito entre nós (como as notificações e citações judiciais para produzirem efeitos alhures);

d. sua permanência no território nacional pelo tempo que bem julgar o Estado que envia, mas sujeita à vigência da autorização do Estado receptor para o exercício das funções consulares, que pode terminar, nos termos do art. 25 da Convenção de Viena sobre Relações Consulares, pela notificação do Estado que envia ao Estado receptor de que aquelas funções chegaram ao fim; pela retirada do exequatur, unilateralmente, pelo Estado receptor, e pela notificação deste Estado, de que deixou de considerar a pessoa em apreço como membro do pessoal consular (nos dois últimos casos, a situação é semelhante à consideração de "persona non grata", como no caso dos diplomatas).

Ora, nenhuma pessoa poderá realizar tais atos típicos da função consular, que esquematicamente descrevemos, e cuja enumeração se encontra no art. 5o da Convenção de Viena sobre Relações Consulares ("Funções Consulares"), salvo no caso de estar investida nas mesmas, na qualidade de agente do Estado estrangeiro, e como tal, na condição de estar autorizado pelo Governo federal, a entrar e permanecer no território nacional, bem como a exercer seus atos típicos.

É necessário dizer que tais normas, que criam privilégios e imunidades de jurisdição, são autênticas restrições de direitos subjetivos públicos, em particular, do direito à ação civil, expressamente consagrado pela norma constitucional brasileira, no art. 5o, inc. XXXV, da Constituição Federal de 1988, que proibe ao legislador ordinário subtrair ao exame do Poder Judiciário qualquer lesão ou ameaça a direito. Ora, sendo normas de restrição de direitos individuais, devem ser interpretadas restritivamente, segundo o adágio "odiosa restringenda". Isto posto, uma leitura do art. 5o da Convenção de Viena sobre Relações Consulares, com olhos de um intérprete a quem se proíbe a exegese por analogia, conduz à conclusão de que a celebração de contratos de 
trabalho entre a repartição consular e o empregado brasileiro ou estrangeiro (sendo mesmo irrelevante se os contratos foram assinados no Brasil ou alhures, dado que o que interessa é o lugar da prestação do trabalho), não se inclui entre as citadas funções consulares. Na verdade, se ao juiz brasileiro está vedado examinar os atos referentes à função consular, daí nada se pode inferir quanto a eventuais proibições de examinar atos, como contratos trabalhistas, que não se incluem naquele rol de atos oficiais da função consular.

No exame da jurisprudência brasileira dos últimos anos, verifica-se que as alegações de imunidades de jurisdição ocorreram nos seguintes casos: a. contratos de construção civil entre Embaixada de país estrangeiro e empresa brasileira; b. inúmeros contratos de locação de imóveis entre autores brasileiros e Missões diplomáticas ou repartições consulares de países estrangeiros; c. acidentes de trânsito, que envolveram reclamações de responsabilidade civil, contra pessoa estrangeira investida de imunidades de jurisdição; d. e os casos mais freqüentes, de inadimplência de contratos de trabalho, sendo o reclamante um indivíduo domiciliado no Brasil e o reclamado, uma das pessoas investidas das referidas imunidades de jurisdição. Na maioria das vezes, com exceção dos últimos casos a seguir relatados e que ocorreram na Justiça do Trabalho, foram as citadas imunidades de jurisdição, ou invocadas, ou declaradas ex officio pelo juiz brasileiro (no caso de não-resposta a uma citação judicial válida), e pela simples verificação de que os réus ou reclamados eram diplomatas ou cônsules estrangeiros os feitos judiciais foram declarados extintos, pela impossibilidade do pedido.

Tão freqüentes têm sido as questões trabalhistas relativas a imunidades de jurisdição, que houve mesmo a emergência de um conflito de jurisdição entre a Justiça do Trabalho e a Justiça Federal ordinária. Na verdade, nas reclamações trabalhistas propostas contra Missões diplomáticas ou Repartições consulares, na letra da Constituição federal anterior havia a lacuna de se saber qual a justiça competente, se a federal geral ou se a justiça trabalhista (ainda que se reconhecesse ser esta federal, mas, por ser especializada, havia a perplexidade), por ser o reclamado um ente de Direito Internacional Público. Dos julgamentos do mencionado conflito de jurisdição resultaria a Súmula 83 do então Tribunal Federal de Recursos, assim redigida: 


\begin{abstract}
"Compete à Justiça Federal processar e julgar reclamações trabalhistas contra representação diplomática de país estrangeiro, inclusive para decidir sobre a preliminar de imunidade de jurisdição".
\end{abstract}

Contudo, não houve qualquer súmula semelhante no que respeita a reclamaçöes trabalhistas contra repartições consulares de país estrangeiro.

$\mathrm{Na}$ verdade, com a promulgação da vigente Constituição Federal de 1988, o conflito cessou de existir, uma vez que o seu art. 114 expressamente assim estatui:

\title{
"Art. 114 - Compete à Justiça do Trabalho conciliar $e$ julgar os dissídios individuais e coletivos entre trabalhadores, abrangidos os entes de direito público externo e da administração pública direta ou indireta..." (ênfase nossa).
}

Em que pese a imperfeição conceitual de entes de direito público externo (a terminologia correta seria: entes de direito internacional público) do referido art. 114 da Constituição Federal de 1988, conclui-se tratar-se:

a. o empregador: Estados estrangeiros ou organizações internacionais intergovernamentais, por qualquer maneira que seja, inclusive através de intervenção dos agentes do Estado estrangeiro no Brasil, ou seja, funcionários das suas missões diplomáticas ou das suas repartições consulares localizadas no território nacional;

b. os dissídios individuais ou coletivos: aqueles surgidos, seja de contratos celebrados alhures, seja, especialmente, de contratos celebrados no território nacional (sem ter relevância a distinção de ser o trabalhador um brasileiro ou um estrangeiro, por força do princípio da isonomia entre nacionais e estrangeiros, conforme consagrado no caput do art. 5o da mesma Constituição Federal);

c. a lei de regência do contrato: qualquer lei nacional de um país determinado (seja a brasileira, seja a estrangeira), mas com exclusão das normas de Direito Internacional Público, em particular aquelas constantes das Convenções de Viena de 1961 e de 1963 (uma vez que o legislador constituinte 
atribuiu à Justiça brasileira a competência de julgar os contratos, porque as prestações laborais são realizadas no território nacional).

$\mathrm{Na}$ verdade, deve considerar-se que os contratos de trabalho celebrados, de um lado, por uma missão diplomática ou por uma repartição consular estrangeiras, e de outro, um trabalhador submetido à lei trabalhista brasileira, não são atos negociais celebrados por funcionários diplomáticos ou consulares, a título personalíssimo (salvo no caso do "criado particular" ou "membro do pessoal privado", na terminologia das Convenções de Viena), mas atos praticados em nome do Estado estrangeiro. Isto posto, segue-se que as relações trabalhistas se estabelecem entre o indivíduo e o próprio Estado estrangeiro, não havendo, pois, como invocar-se a regra do Direito Internacional Público, conforme constante nas mencionadas Convenções de Viena de 1961 e de 1963, mas em outros princípios legais, inclusive para definir-se o problema central das discussões: a própria existência daquelas imunidades de jurisdição.

A própria evolução da jurisprudência brasileira mostra a impropriedade de tentar-se aplicar as mencionadas Convenções de Viena para a resolução de assuntos ligados a outras esferas normativas, pois até o julgamento da Apelação Cível n. 9.696-3/SP, sendo apelante Genny de Oliveira e apelada a Embaixada da então República Democrática Alemã, (D.J. 24.10.1990, p. 11.828, em republicação), que brevitatis causa denominaremos Caso Geny de Oliveira/90, o raciocínio tinha sido de que, por tratar-se de atos celebrados por diplomatas stricto sensu ou por funcionários consulares estrangeiros, estariam eles acobertados pelas imunidades, e, portanto, não haveria possibilidade de a Justiça brasileira manifestar-se sobre o mérito das reclamações trabalhistas ajuizadas.

Como já mencionamos, é outro caminho que deve ser buscado no deslinde das questões que suscitam os contratos de trabalho celebrados entre o indivíduo e o Estado estrangeiro, e seu exame pelos Poderes Judiciários dos Estados. Já mencionamos as razóes que, acreditamos, teriam feito surgir o fenômeno da crescente apresentação perante os citados Poderes Judiciários, de ações contra Estados estrangeiros: relembramos, de igual forma, os motivos que forçaram o estabelecimento de regras sobre a competência das Justiças estatais, nas ações que envolvem um Estado estrangeiro, e dentre estes, pudemos afirmar que existe tão-somente uma regra internacional, a Convenção Européia sobre 
Imunidades do Estado, assinada a 16 de maio de 1962, na Basiléia, mesmo assim, de vocação regional. Deixamos dito que, em alguns países da Common Law (EUA, Reino Unido, Canadá, Austrália, Paquistão e Singapura), foram passadas leis nacionais escritas (statutes), que buscaram resolver a questão. Falta dizer algo sobre os países da Civil Law, ou melhor dito, da familia de direitos romanogermânica e a sua evolução jurisprudencial (pois foi este o caminho trilhado, e não a passagem de leis escritas).

No caso dos direitos da Common Law, mencionados, houve um momento preciso e punctual, a partir do qual o assunto passou a ser tratado: a passagem dos mencionados statutes; a partir deles, os precedentes jurisprudenciais anteriores (stare decisis), tão caros àquela família de direitos, tornaram-se inoperantes como fontes de regras para soluções das questões, então novíssimas no direito. Trata-se de leis que buscam estabelecer, de maneira pragmática, uma tipologia dos atos praticados pelos Estados estrangeiros, que podem ser ou não ser examinados pelos Poderes Judiciários domésticos: são diplomas casuísticos, onde se busca traçar um rol aproximativo de certos atos, imunes à jurisdição, ou não imunes. No caso dos direitos da família romanogermânica, não houve edição de leis escritas, mas houve, sim, a emergência de uma jurisprudência dos tribunais internos, no sentido de distinguir (sob as denominações iniciais e originais de acta jure imperii e acta jure gestionis), os atos praticados pelo Estado estrangeiro, que merecem ser considerados imunes à jurisdição dos tribunais nacionais, e aqueles que podem ser examinados e julgados por estes.

O caso da Convenção Européia de 1962, por se tratar de uma lei escrita, mereceu uma comparação com outra lei escrita, o United Kingdom State Immunity Act 1978, já mencionado no nosso trabalho Das imunidades de jurisdição e de execução (1984), verbis, p. 150-151:

"Não se beneficia das imunidades o Estado estrangeiro que:

a. por sua conduta (mais do que pela natureza do ato) se submete à jurisdiçāo das cortes do Reino Unido, tais como iniciar uma açāo ou intervir no processo (salvo para invocar a imunidade), entendendo-se como 
pessoas que assim podem fazer, o chefe da missão diplomática ou as pessoas tituladas para agir em nome do Estado, em contratos (Seção 2);

b. pela natureza de u'a atividade, o UK-Act o submete às suas cortes, tais:

1. situações contratuais: contratos comerciais ou nāo, exeqüiveis no Reino Unido, contratos de trabalho, disposiçōes essas iguais às da Convenção Européia;

2. procedimentos relativos à responsabilidade extracontratual, idem;

3. procedimentos relativos à propriedade de bem imóvel sito no Reino Unido, ou advinda de sucessão ou doação, idem;

4. procedimentos relativos a direito de propriedade intelectual ou industrial, idem;

5. procedimentos relativos a assuntos interna corporis' em que um Estado se encontra frente a uma sociedade ('body corporate, incorporated body or a partnership'), idem;

6. submissão à arbitragem no Reino Unido, salvo disposição compromissória diferente ou quando as partes forem Estados, idem,

c. nos casos de Direito Marítimo (ações in rem e in personam) relativas à operação de navios da propriedade do Estado estrangeiro (sec. 10) e nos de procedimentos relativos a tributos e taxas, verbis:

Sec. 11. A State is not immune as respect proceedings relating to its liability for

a. value added tax, any duty of customs or exercises or any agricultural levy; or

b. rates in respect of premises occupied by it for commercial purposes.

Além do catálogo específico, mencionado, a Seção 3 do UK-Act contém uma disposiçāo de caráter geral, que 
isenta o Estado estrangeiro das imunidades de jurisdição nos procedimentos relativos a transações comerciais, assim definidas na subseção 3, verbis:

a. qualquer contrato de suprimento de bens $e$ serviços;

b. qualquer empréstimo ou outra transação para a provisão de recursos financeiros e qualquer garantia ou indenização relativa àquela transação ou qualquer outra obrigação financeira; $e$

c. qualquer outra transaçâo ou atividade (comercial, industrial, financeira, profissional ou de caráter similar) em que o Estado participe ou exerça, e que não seja no exercício de sua atividade soberana".

Importantes estudos da jurisprudência que se seguiu a partir da edição dos statutes nos referidos países da Common Law (em particular os mencionados cursos na Haia de Sir Ian Sinclair e de Peter D. Trooboff), mostram a formação de uma distinção, em algo similar à existente nos países da familia romano-germânica, e que acabaram por incorporar-se na regra da Section 451 do Revised Restatement of the Foreign Relations Law of the USA, que distingue "govermmental activities (de jure imperii) and activities of the kind that may also be carried on by private persons (de jure gestionis), notably commercial activities..."

$\mathrm{Na}$ verdade, a distinção entre acta jure imperii (atos praticados por Estados estrangeiros e que não podem ser apreciados pelos Poderes Judiciários de outros Estados, porque relevantes da potestas normativa e administrativa interna daqueles) e acta jure negotii, ou ainda denominados acta jure gestionis (atos de Estados estrangeiros passíveis daquele exame e julgamento, porque susceptíveis de serem praticados, igualmente, por simples particulares) é uma criação da jurisprudência da Bélgica e do Egito, do final do século XIX. Criticada por grandes autores, na base de que não se pode descaracterizar atos praticados pela mesma pessoa, o Estado (pense-se numa operação de compra de armamentos, realizada por um Estado de um particular estrangeiro, para suprir suas Forças Armadas, ou nos contratos rotineiros de construção civil de obras 
públicas, em concorrências internacionais abertas a particulares estrangeiros) segundo a ótica do interesse da outra parte, o particular estrangeiro, ou segundo a ótica dos interesses do Estado, aquela distinção, contudo acabou por se impor, pela sua utilidade. Na verdade, aquela distinção foi aos poucos ganhando outras roupagens, como as oposiçóes conceituais entre atos de Governo e atos como simples particular, ou ainda, atos públicos do Estado e atos do Estado enquanto particular, etc. $\mathrm{O}$ citado professor Trooboff reconhece que não foi difícil à jurisprudência dos países da família romano-germâmica elaborar conceitos refinados, com base numa distinção fundamental que nela existe, e que é estranha aos países da Common Law: a dialética da oposição ideal-típica entre as esferas do Direito Público e do Direito Privado.

O caso Genny de Oliveira/90 merece destaque, pois, como já se disse, reformou a jurisprudência do Supremo Tribunal Federal do Brasil e colocou o País em consonância com os princípios que regem a matéria, na imensa maioria dos países da atualidade. Num momento histórico em que os Estados alargam suas atividades no que respeita ao domínio econômico e em que restringem ao máximo as possibilidades de invocação de imunidades de jurisdição para o Estado-empresário, para tornar seus Judiciários exemplarmente conformes ao respeito dos direitos subjetivos da pessoa humana, particularmente no que concerne ao acesso da pessoa humana aos tribunais nacionais, não fazia sentido o País manter-se aferrado ao princípio da imunidade absoluta de jurisdição dos Estados estrangeiros, em detrimento da proteção daqueles direitos subjetivos.

Em particular, na atualidade brasileira, em que a matéria dos contratos de trabalho com o Estado estrangeiro voltou a ser da competência da Justiça do Trabalho, por força do mencionado art. 114 da Constituição Federal de 1988, tudo indica que a jurisprudência laboral seguirá as linhas daquele leading case, que, por sinal, ainda em casos remanescentes da Justiça Federal sobre o assunto, acabou por determinar o resultado do julgamento da Apelação Cível n. 2 (89.8751-7) pelo Superior Tribunal de Justiça, em acórdão de 07 de agosto de 1990 (apelante, a Embaixada dos EUA em Brasilia e apelados, Paulo da Silva Valente e outro, publicado in D.J. de 03 de setembro de 1990). Eis a ementa deste acórdão: 
"Imunidades de Jurisdição. Reclamação Trabalhista intentada contra Estado estrangeiro. Sofrendo o princípio da imunidade absoluta de jurisdição certos temperamentos, em face da evolução do direito consuetudinário internacional, não é ela aplicável a determinados litígios decorrentes de relaçōes rotineiras entre Estado estrangeiro e os súditos do país em que o mesmo atua, de que é exemplo a reclamaçāo trabalhista. Precedentes do STF e do STJ. Apelo a que se nega provimento".

Na verdade, o caso Genny de Oliveira/90 já tivera um exame anterior pelo Supremo Tribunal Federal (que tínhamos analisado em nossa obra citada, que fora escrita em 1980, editada porém em 1984) razão pela qual tivemos o cuidado de batizar-lhe com a nomeação do ano da prolação do último acórdão a ela relativo. Um estudo crítico do e preciso do mesmo encontra-se na obra do professor doutor Georgenor de Souza Franco Filho, titular de Direito Internacional Público e Privado da União das Escolas Superiores do Estado do Pará (UNESPA) e Juiz Presidente da 4a Junta de Conciliação e Julgamento de Belém, Da distinção entre atos de império e de gestão e seus reflexos sobre os contratos de trabalho celebrados com entes de Direito Internacional Público, apud Georgenor de Souza Franco Filho (coordenador), Direito do trabalho e a nova ordem constitucional, São Paulo, LTr, 1991 (em particular, p. 45-46). Eis a ementa do acórdão publicado em 1990, do qual foi relator o insigne Ministro Sydney Sanches:

"Estado estrangeiro. Imunidade de jurisdição. Causa trabalhista.

1. Não há imunidade de jurisdição para o Estado estrangeiro, em causa de natureza trabalhista.

2. Em princípio, esta deve ser processada e julgada pela Justiça do Trabalho, se ajuizada depois do advento da Constituição Federal de 1988 (art. 144).

3. Na hipótese, porém, permanece a competência da Justiça Federal, em face do disposto no parágrafo 10 do 
art. 27 do A.D.C.T. da Constituição Federal de 1988, c/c art. 125, II da EC n. 1/69.

4. Recurso ordinário conhecido e provido pelo Supremo Tribunal Federal para se afastar a imunidade de jurisdição reconhecida pelo Juizo Federal de $1^{\circ}$ grau, que deve prosseguir o julgamento da causa, como de direito".

Tratou-se de uma reclamação trabalhista intentada pela Sra. Genny de Oliveira, viúva de antigo funcionário da Representação Comercial da então República Democrática Alemã em São Paulo (em fase posterior do processo, reconhecida como parte integrante da Missão diplomática daquele País no Brasil, sita em São Paulo), para o fim de compelir a reclamada a realizar anotações no contrato de trabalho do falecido marido, inclusive das alterações havidas, em particular, com relação aos salários pagos. Face às alegações de imunidades de jurisdição da reclamada, que invocou a Convenção de Viena sobre Relações Diplomáticas, tendo a MM. Junta de São Paulo afastado a alegação e reconhecido que um contrato de trabalho não configurava um ato de império, proferiu decisão em que julgou procedente a reclamação. O TRT da $2^{\mathrm{a}}$ Região, através de recurso ordinário, reformaria a decisão $a$ quo, para conhecer da preliminar da imunidade de jurisdição, na base do argumento de que a reclamada passara a ser reconhecida como parte integrante da Embaixada da RDA em Brasília (com fundamento no art. 125, II da EC n. 1/69), e, sendo assim, remeteu os autos para a Justiça Federal. O Juiz Federal da 8 a Vara de São Paulo deu-se por incompetente e suscitou conflito de jurisdição para o STF; este, conheceu do conflito para declarar a competência da Justiça Federal (e, portanto, é esta a primeira vez em que a Suprema Corte conheceria sobre o caso Genny de Oliveira), tendo devolvido os autos à mesma para decisão de meritis.

O MM. Juiz Federal da $1^{a}$ Vara de São Paulo julgaria a reclamante carecedora de ação, por ter reconhecido a ocorrência de imunidade de jurisdição da Embaixada da República Democrática da Alemanha, conforme a Convenção de Viena sobre Relações Diplomáticas. De tal decisão, foi interposto recurso ordinário para o Tribunal Federal de Recursos, que, ao não conhecê-lo, remeteu os autos ao E. Supremo Tribunal Federal, que seria competente para o 
julgamento de recursos em causas em que forem partes um Estado estrangeiro e pessoa domiciliada ou residente no território nacional, tendo ficado provado que o antigo Escritório Comercial em São Paulo passara a fazer parte integrante da Embaixada da RDA em Brasilia, caracterizando-se, assim, uma relação laboral entre uma Missão diplomática estrangeira e uma pessoa residente ou domiciliada no Brasil. Ainda no seu relatório, o Em. Ministro Sydney Sanches cita uma série de precedentes em julgados brasileiros, em que se afirmara a regra da existência das imunidades de jurisdição, com base na citada Convenção de Viena, e a necessidade de haver uma renúncia formal dos titulares daquelas imunidades para que o Judiciário brasileiro pudesse conhecer da reclamação. Enfim, o Ministério Público opinaria sobre o conhecimento do recurso, porém pelo seu improvimento.

No seu voto, o Ministro Relator confirma a competência da Justiça Federal, in casu, em virtude do art. 27, § 10 do Ato das Disposições Transitórias da Constituição Federal de 1988, por se tratar de processo pendente, no advento da norma constitucional; bem assim, diz ser, nos casos futuros, a competência para casos como os sub judice, da competência da Justiça do Trabalho, com base no art. 114 da Norma Suprema. Nas suas razões de decidir, assim se pronunciou o Ministro Relator:

"Afinal, o que ditou a eliminação da imunidade foi a natureza da causa trabalhista - e não a competência deste ou daquele órgão do Poder Judiciário. Assim, conheço da apelação e, em face do direito constitucional superveniente, que pode ser considerado neste recurso ordinário (art. 462 do $\mathrm{CPC}$ ), e que eliminou a imunidade do Estado estrangeiro, em causa de natureza trabalhista, dou provimento à apelação para cassar a respeitável sentença do $1^{o}$ grau, que se baseara no direito anterior, e determinar que o nobre Magistrado, superada que ficou essa questão, prossiga no julgamento da causa, como de direito".

Adiado o julgamento, em virtude do pedido de vista por parte do eminente Ministro Francisco Rezek, assim se pronunciou S. Exa., também pelo 
provimento do recurso, mas por razões bem diferentes daquelas expedidas pelo Ministro Relator. Na verdade, com seu voto, o Ministro Rezek traçaria uma clara evolução do instituto das imunidades de jurisdição, com erudita argumentação, que acabaria por fundamentar os votos que se seguiram e que determinaram o reconhecimento no Brasil da inexistência das imunidades de jurisdição, em relações trabalhistas, em decisão unânime (em que pese terem as razões invocadas pelo Ministro Relator servido de fundamento apenas à sua decisão pessoal e, concorrentemente, à do Ministro Paulo Brossard). Portanto, vale a pena examinar o voto do Ministro Rezek, que, sem dúvida, motivou a primeira decisão do Supremo Tribunal Federal em que se rejeitaram as alegações de imunidades de jurisdição, lançando as bases para que a jurisprudência brasileira se coloque de acordo com a tendência universal de nossos dias, que é a de restringir, o quanto se possa, as imunidades de jurisdição, de maneira muito particular nas relações processuais trabalhistas, a fim de se evitar o abominável fenômeno da denegação de justiça a um hipossuficiente.

Em resumo, o voto do Ministro Rezek pode assim ser esquematizado:

a. é necessário distinguir as imunidades que se tem verificado, na jurisprudência do Supremo Tribunal Federal, nas suas duas vertentes: aquelas pessoais, resultantes das duas Convenções de Viena (sobre relações diplomáticas e sobre relações consulares), atribuídas a um réu, pessoa física, e nas quais opera em plenitude, o direito internacional escrito; e aquelas que são atribuídas ao próprio Estado estrangeiro;

b. as primeiras raramente têm sido invocadas perante o Supremo Tribunal Federal, o mesmo não ocorrendo em relação às segundas;

c. o fundamento da jurisprudência do Supremo Tribunal Federal, em relação às imunidades do próprio Estado (como no caso sub judice, nas relações trabalhistas), se tinha firmado numa regra costumeira então vigente, das imunidades absolutas do Estado estrangeiro perante os tribunais brasileiros, regra essa que deixou de existir a partir de 1972, com a edição da Convenção Européia da Basiléia sobre as imunidades do Estado, reafirmada com as leis dos EUA e do Reino Unido, que introduziram temperamentos na teoria da imunidade absoluta do Estado estrangeiro; 
d. isto posto, não havendo solidez na regra costumeira de Direito Internacional, o fundamento da jurisprudência anterior do Supremo Tribunal Federal desapareceu, havendo, assim, a necessidade de acomodar a jurisprudência do mesmo à nova realidade (não tendo mudado o quadro interno, mas o internacional) e, portanto, não se encontra "fundamento para estatuir sobre a imunidade como vinha garantindo o Supremo Tribunal Federal". Eis o cerne da decisão:

"O que caiu foi o nosso único suporte para a afirmação da imunidade numa causa trabalhista contra o Estado estrangeiro, em razāo da insubsistência da regra costumeira que se dizia sólida - quando ela o era e que assegura a imunidade em termos absolutos.

Com essas razóes, também voto no sentido de dar causa ao deslinde proposto pelo Ministro Relator. Não me apoio no art. 114 da Constituiçāo de 1988, mas no fato de não mais encontrar fundamento para estatuir sobre a imunidade como vinha garantindo o Supremo Tribunal Federal".

Foi com especial satisfação que lemos o voto decisivo do eminente Ministro Francisco Rezek e os demais votos que adotaram como razão de decidir, os argumentos de S. Exa. Na verdade, correspondem aqueles conceitos aos que expusemos nas conclusões de nossa tese de livre-docência em Direito Internacional, defendida em 1980, perante a Faculdade de Direito da Universidade de São Paulo e que resultaria no nosso trabalho anteriormente mencionado e publicado pela Editora Forense. Permitimo-nos transcrever um trecho das conclusões de nossa tese:

"Apesar das dificuldades, contudo, alguns pontos comuns podem ser achados no exame das várias imunidades. $O$ primeiro e principal é a tendência de restringi-las ao quanto se puder, numa tentativa de deixar os Poderes Judiciários o mais abrangente possivel, seja por motivações de soberania nacional, 
seja por outras de equilibrio constitucional entre os três Poderes, seja, ainda numa ótica de proteção da pessoa de direito privado, que não tem privilégios ou imunidades e, por isso, deve uma atenção especial, quando em relações jurídicas com pessoas imunes..." (Guido Fernando Silva Soares, Das imunidades de jurisdição e de execução, Rio de Janeiro, Forense, 1984, p. 229-230).

Finalmente, é interessante observar a seqüela do caso Genny de Oliveira/1990, em particular no que respeita à atitude tomada pelo Ministério das Relações Exteriores do Brasil, com relação ao assunto e "a fim de atender às freqüentes consultas sobre processos trabalhistas contra Representações Diplomáticas e Consulares". Trata-se da Nota Circular n. 560, DJ/DPI/CJ, de 14 de fevereiro de 1991, do Ministério das Relações Exteriores do Brasil, dirigida às Missões diplomáticas acreditadas em Brasília, cujo conhecimento nos foi possível pela leitura do referido artigo $D a$ distinção entre atos de império e de gestão..., de autoria do professor e magistrado trabalhista Dr. Georgenor de Souza Franco Filho, publicado no livro, igualmente já mencionado, de que S. Exa. foi coordenador, Direito do trabalho e a nova ordem constitucional, apud, p. 34-35. Eis seus pontos básicos:

'a. em virtude do princípio da independência dos Poderes, consagrado em todas as Constituiçōes brasileiras, e que figura no artigo segundo da Constituição de 1988, é vedada ao Poder Executivo qualquer iniciativa que possa ser interpretada como interferência nas atribuições de outro Poder;

b. a Convenção de Viena sobre Relaçōes Diplomáticas de 1961, assim como a de 1963, sobre Relaçōes Consulares, não dispöe sobre matéria de relações trabalhistas entre Estado acreditante e pessoas contratadas no território do Estado acreditado;

c. ante o exposto na letra b, os Tribunais brasileiros, em sintonia com o pensamento jurídico atual, que 
inspirou, aliás, a Convenção Européia sobre Imunidades dos Estados de 1972, o "Foreign Sovereign Immunities Act" dos Estados Unidos da América, o "State Immunity Act", do Reino Unido, de 1978, firmaram jurisprudência no sentido de que as pessoas jurídicas de direito público externo não gozam de imunidades no domínio dos "atos de gestão", como as relaçōes de trabalho estabelecidos localmente;

d. a Constituição brasileira em vigor determina, em seu artigo 144, ser da competência da Justiça do Trabalho o conhecimento e julgamento desses litigios"

Acreditamos que não podemos, em que pese a ponderação do professor Souza Franco Filho, assimilar a referida Nota Circular do Ministério das Relações Exteriores do Brasil, nem ao Act dos EUA, como sugere S. Exa., nem, como poderia aparecer, à primeira vista, à famosa Tate Letter, comunicação do consultor jurídico, em exercício, do Departamento de Estado dos EUA, em 19 de maio de 1952 (portanto, antes do FSLA, que é de 1976), ao então consultor-geral Philip B. Perlman, para esclarecer a posição do Poder Executivo norte-americano, no que se referia ao tema das imunidades de jurisdição, numa época em que a jurisprudência federal daquele País se mostrava em estado caótico. Em primeiro lugar, reconhecendo com aquele Professor, que se trata de Nota oriunda do Poder Executivo, não pode ela ser assimilada a um statute da Common Law federal dos EUA, uma vez que suas normas se dirigem a Missões diplomáticas estrangeiras acreditadas em Brasilia, e, portanto, não têm efeito erga omnes. Quanto às possíveis assimilações à Tate Letter, a própria Nota Circular n. 560 do Ministério das Relações Exteriores do Brasil, expressamente na sua letra $b$, reconhece a independência dos três Poderes (leia-se, em especial, do Poder Judiciário em relação ao Poder Executivo) e, sendo assim, não corre o perigo de ser considerada uma ingerência indevida da Administração nas atribuições dos tribunais judiciários (como, de fato, ocorreu nos EUA, o que causou o total desconhecimento, por parte dos tribunais norte-americanos, das normas contidas na citada comunicação do consultor jurídico da Secretary of State daquele País). O que se depreende, pois, da citada Nota Circular, é que se 
trata de um conselho às Missões diplomáticas estrangeiras acreditadas no Brasil, a que façam atenção às eventuais inadimplências de suas obrigações legais trabalhistas, que, doravante, serão plenamente conhecidas e julgadas pelos tribunais de Justiça do Trabalho do Brasil, podendo ler-se, nas entrelinhas, que o Ministério das Relações Exteriores nada tem a ver com as conseqüências de tal fato, em particular, no que respeita a possíveis violações de obrigações internacionais do País, no que respeita a alegações de imunidades de jurisdição por parte das referidas Missões diplomáticas acreditadas perante o Governo Federal em Brasilia.

Como conclusão, devemos dizer que o abandono da teoria da imunidade absoluta por parte da Justiça Trabalhista no Brasil, para torná-la abrangente dos contratos de trabalho de pessoas domiciliadas no Brasil, com Missões diplomáticas ou Repartições Consulares, ou seja, com o próprio Estado estrangeiro, além de colocar o País em correspondência com os direitos internos da esmagadora maioria dos Estados da atualidade, reafirma a vocação do Brasil de respeitar um dos princípios fundamentais da Declaração Universal dos Direito do Homem, solenemente proclamada pela Assembléia Geral das Nações Unidas, a 10 de dezembro de 1948, no seu art. VIII, verbis:

"Todo homem tem direito a receber dos tribunais nacionais competentes remédio efetivo para os atos que violem os direitos fundamentais que the sejam reconhecidos pela constituição ou pela lei".

\section{BIBLIOGRAFIA BRASILEIRA RECENTE}

ALMEIDA, Isis de. Substituição processual; isenção ou imunidade de jurisdição. In: Manual de direito processual do trabalho. São Paulo : LTr, 1988. p. 1067;130-2.

DOLLINGER, Jacob. A imunidade estatal à jurisdição estrangeira. In: A nova Constituição e o direito internacional. Rio de Janeiro : Freitas Bastos, 1987. p. 195-208. 
Estado estrangeiro. Imunidade de jurisdição. Causa trabalhista. Revista LTr: Legislação do Trabalho e Previdência Social, São Paulo, v. 55, n. 1, p. 45-50, jan. 1991.

FRANCO FILHO, Georgenor de Souza. Da imunidade de jurisdição trabalhista e o art. 114 da Constituição de 1988. Revista do Tribunal Regional do Trabalho da $8^{a}$ Regiāo, Belém, v. 24, n. 46, p. 75-84, jan.-jun. 1991.

FRANCO FILHO, Georgenor de Souza (coordenador). Direito do trabalho e a nova ordem constitucional. São Paulo : LTr, 1991. 219 p.

FRANCO FILHO, Georgenor de Souza. Imunidades de jurisdição trabalhista dos entes do direito internacional público. São Paulo : LTr, 1986. 112 p.

Imunidade de jurisdição. Reclamação trabalhista contra Estado estrangeiro. Convenção de Viena. Revista LTr: Legislação do Trabalho e Previdência Social, São Paulo, v. 50, n. 11, p. 1310, nov. 1986.

Imunidade de jurisdição. Reclamação trabalhista intentada contra Estado estrangeiro. Revista LTr: Legislação do Trabalho e Previdência Social, São Paulo, v. 55, n.5. p. 597-603, mai. 1991.

Jurisdição. Imunidade. Competência para declará-la. Súmula n. 83 do T.F.R. Orlando Teixeira da Costa (Relator). Revista do Tribunal do Trabalho, $8^{\underline{a}}$ Região, Belém, v. 17, n. 32. p. 131-33, jan.-jun. 1984.

Jurisdição. Imunidade. Reclamação trabalhista contra Estado estrangeiro. Revista LTr: Legislaçāo do Trabalho e Previdência Social, São Paulo, v. 54, n. 9, p. 1109-1111, set. 1990.

MAGAlHÃES, José Carlos de. Da imunidade de jurisdição do Estado estrangeiro perante a justiça brasileira. In: $A$ nova Constituição e o direito internacional. Rio de Janeiro : Freitas Bastos, 1987. p. 209-220.

Organização da Aviação Civil Internacional. Imunidade de jurisdição. Revista LTr: Legislação do Trabalho e Previdência Social, São Paulo, v. 54, n. 5, p. 539-41, mai. 1990.

PARANHOS, C. A. Teixeira. A imunidade de jurisdição dos organismos internacionais na visão do STF. Revista LTr: Legislação do Trabalho e Previdência Social, v. 47, n. 9, p. 1060-63, set. 1983.

Reclamação contra repartição consular. Hipótese de inexistência de imunidade de jurisdição. Competência da Justiça do Trabalho. Assistência da União. 
Revista Regional do Trabalho da $8^{a}$ Regiāo, Belém, v. 17, n. 32, p. 166-172, jan.-jun. 1984.

RUSSOMANO JR., Victor. Imunidade de jurisdição trabalhista e revelia no processo de conhecimento. Revista LTr: Suplemento Trabalhista, São Paulo, v. 23, n. 135, p. 601-602, 1987.

SOARES, Evanna. A imunidade de jurisdição nos dissídios trabalhistas, envolvendo entes de direito público externo. Revista LTr: Legislação do Trabalho e Previdência Social, São Paulo, v. 55, n. 12, p. 1419-1922, dez. 1991.

SOARES, Guido Fernando Silva. Das imunidades de jurisdição e de execução. Rio de Janeiro : Forense, 1984. 264 p.

STURZENEGGER, Luiz Carlos. Imunidades de jurisdição e de execução dos Estados: proteção a bens de Bancos Centrais. Revista do Direito do Comércio e das Relações Internacionais, São Paulo, n. 2, p. 47-88, 1990-91. 